\title{
THE LENNIX SYNTHETIC EMERALD
}

\author{
By Giorgio Graziani, Edward Gübelin, and Maurizio Martini
}

The Lennix synthetic emerald, currently manufactured in France, is a dark green. moderately transparent to translucent material grown by flux fusion. With the microscope, zones of lighter and darker green are evident. For the most part, the gemological properties of this synthetic emerald overlap those of natural emeralds, although the low refractive-index and specific-gravity values are good indicators that this material is synthetic. The presence of "wispy veil" inclusions provides conclusive proof of synthetic origin, as do the chemical analyses, infrared transmission spectra, and cathodoluminescence.

\section{ABOUT THE AUTHORS}

Dr. Graziani is protessor of mineralogy at the Universily of Rome; Dr. Gübelin, a prominent gemologist and author, is from Meggen, Switzerland; Dr. Martini is a gemologist at the Laboratory of Gemmological Analysis, Rome.

Acknowledgments: The authors wish to thank Dr. J. Ponahlo, Director of the Austrian Gemmological Research institute of the E.O.G.C., Vienna, for his help with the cathodoluminescence experiments, and Mr. L. Lens, of the French Sociely for the Distribution of Manufactured Products, Cannes, for providing samples and for his much-appreciated suggestions. The work was supported by a grant from the Universify "La Sapienza," Rome, for the study of mineral inclusions, and by a contribution from the Cassa di Risparmio di Roma, ltaly, for gemological research

(c) 1987 Gemological Institute of America
A $s$ the techniques of crystal growth have become Aincreasingly sophisticated, greater numbers and types of synthetic emeralds have entered the marketplace. One of these products, the Lennix synthetic emerald, is currently being manufactured by the Société France pour la Distribution de Produits Manufacturés, in Cannes, France (figure 1). In 1966, Mr. L. Lens, now president of the manufacturing company, first accomplished the synthesis of microscopic emerald clusters. Years of research and refinement followed, and in the period 1982-1983, Mr. Lens finally obtained gem-quality synthetic emeralds in sizes suitable for use in jewelry. Mr. Lens reports that the production capacity of the firm is currently $50,000 \mathrm{ct}$ of rough crystals per year, an amount that could be doubled with the addition of a second furnace. The material is now available in France land has already been mistaken for "African emerald" by some jewelers). Since the distribution of the material is controlled by a Canadian company, it is likely that this material will soon be introduced in Canada and the United States (E. Fritsch, pers. comm., 1987).

Although Farn (1980) examined a number of the early Lennix synthetic emeralds and pointed out some distinctive characteristics of these stones, the present authors felt that a detailed examination of the material and its inclusions was warranted to describe the means by which it could be separated from natural emeralds and other synthetics. To aid in this project, Mr. Lens supplied eight rough crystals and one faceted stone. The samples were first tested for the standard gemological properties, and then chemical analyses, cathodoluminescence, $\mathrm{X}$-ray topography, $\mathrm{X}$-ray diffraction, and advanced inclusion analyses were performed. The results of these tests are provided here.

\section{METHOD OF SYNTHESIS}

Mr. Lens reports that the Lennix synthetic emeralds are 


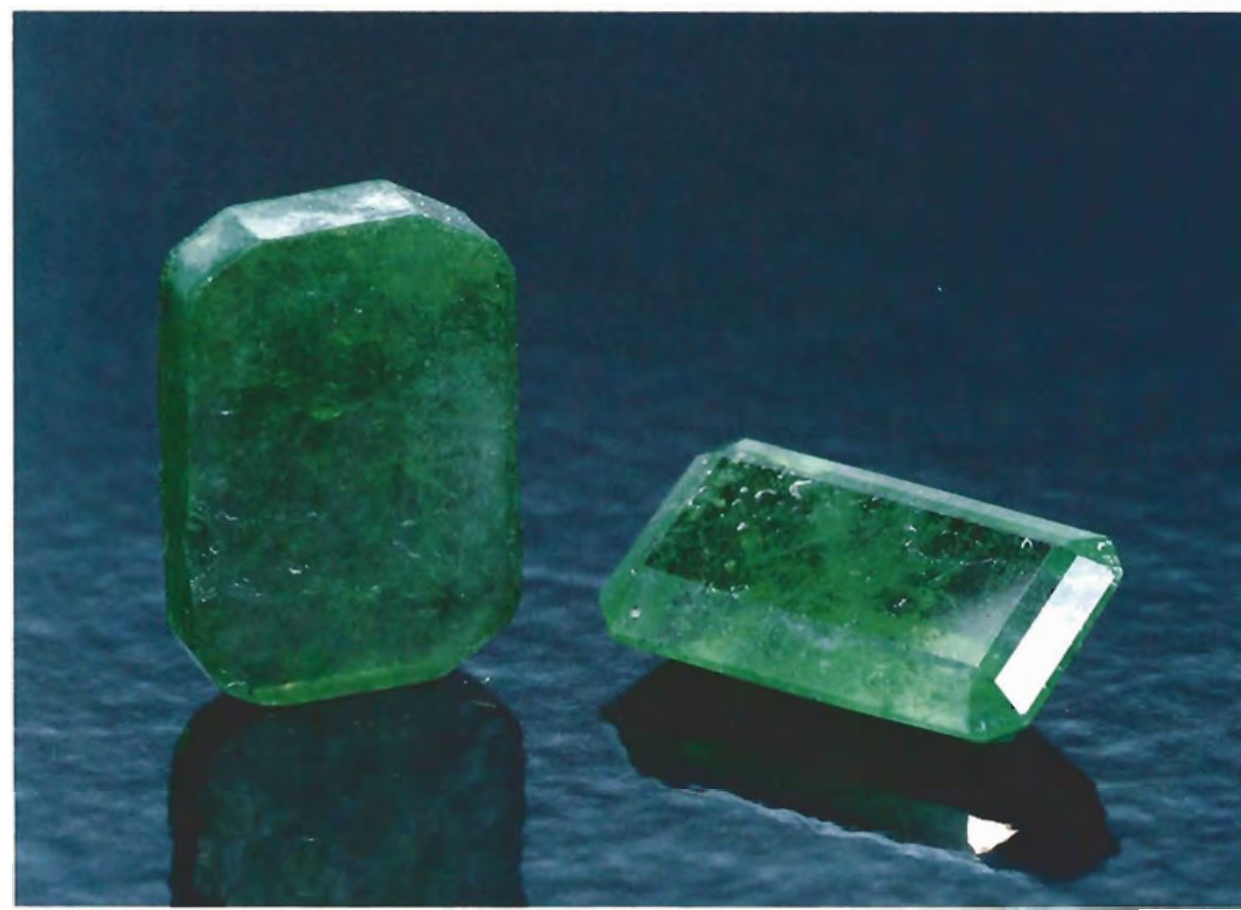

Figure 1. A 1.32-ct fac eted Lennix synthetic emerald and a 1.42-ct crystal section of the material. Photo (c) Tino Hammid.

grown by the flux-fusion process. Crystallization takes place at atmospheric pressure, and follows a rather involved cycle of temperatures, in the region of $1000^{\circ} \pm 100^{\circ} \mathrm{C}$, established to compensate for variations in the composition of the flux during the growth process.

\section{TEST SAMPLES AND VISUAL APPEARANCE}

The synthetic samples examined by the authors are in the form of eight tabular hexagonal crystals and one cut specimen. The rough crystals are characterized by a predominant basal pinacoid. They range in size from $13.9 \times 9.6 \times 3.0 \mathrm{~mm}$ to 9.2 $\times 6.9 \times 3.2 \mathrm{~mm}$; the cut sample weighs $1.30 \mathrm{ct}$ and measures $7.90 \times 6.12 \times 3.12 \mathrm{~mm}$. To the unaided eye, the Lennix synthetic emeralds appear dark green and homogeneous in color lagain, see figure 1). Microscopic observations, however, reveal the presence of more intense peripheral color zones parallel to the c-axis.

The samples range in clarity from moderately to heavily included. Consequently, they vary from stones of medium transparency to those with areas that are translucent to almost opaque.

\section{STANDARD \\ GEMOLOGICAL TESTING}

The samples were subjected to standard gemological tests. The results are shown in table 1 and discussed below.
Refractive Indices. When tested with a gemological refractometer, the faceted Lennix synthetic emerald was determined to be uniaxial negative. Refractive indices were determined on microsamples isolated by means of the MEA apparatus (Graziani, 1983), from within both the light and dark green areas.

The values* are: $\epsilon=1.556-1.562(1.559)$ and $\omega=1.558-1.566(1.562)$, with a corresponding birefringence for the mean values of 0.003 , for the light green areas; and $\epsilon=1.555-1.565(1.560), \omega=$ $1.560-1.568(1.564)$, with a mean birefringence of 0.004 , for the dark green areas. The faceted stone shown in figure 1, for example, revealed refractive indices of $\epsilon=1.559, \omega=1.562$, with a birefringence of 0.003 .

The low values of the light green areas (and the stone in figure 1) are characteristic of flux-grown synthetic emeralds and provide some indication of synthetic origin. However, an identification should not be based on these values alone.

Dichroism. Using a dichroscope, we observed pronounced pleochroic colors of bluish green for the ordinary ray and yellowish green for the extraordinary ray, both also commonly observed in natural emeralds.

"The extreme values of the constants are given, with mean values in parentheses 
TABLE 1. The gemological properties of the Lennix fluxgrown synthetic emerald.

\begin{tabular}{|c|c|}
\hline \multicolumn{2}{|c|}{$\begin{array}{l}\text { Properties that overlap } \\
\text { those of natural emeralds }\end{array}$} \\
\hline Pleochroism & $\begin{array}{l}\text { Strong bluish green parallel to the c-axis; } \\
\text { yellowish green perpendicular to the } \\
\text { c-axis. }\end{array}$ \\
\hline $\begin{array}{l}\text { Absorption } \\
\text { spectruma }\end{array}$ & $\begin{array}{l}\text { Optic-axis direction absorption lines at } \\
477,637,646,662,680 \text {, and } 683 \mathrm{~nm} \text {; a } \\
\text { vague general absorption from } 400 \text { to } 480 \\
\mathrm{~nm} \text { and a broad band of absorption } \\
\text { between } 590 \text { and } 610 \mathrm{~nm} \text {. Perpendicular } \\
\text { to optic-axis direction: same as above, with } \\
\text { the exception that the } 477-\mathrm{nm} \text { line is } \\
\text { absent. }\end{array}$ \\
\hline $\begin{array}{l}\text { Color-filter } \\
\text { reaction }\end{array}$ & Strong red \\
\hline $\begin{array}{l}\text { Fluorescence } \\
\text { Long-wave U.V. } \\
\text { Short-wave U.V. }\end{array}$ & $\begin{array}{l}\text { Bright red } \\
\text { Weak orange-red }\end{array}$ \\
\hline
\end{tabular}

\begin{tabular}{|c|c|}
\hline \multicolumn{2}{|c|}{ Key identifying properties } \\
\hline $\begin{array}{l}\text { Refractive } \\
\text { indices }\end{array}$ & $\begin{aligned} \text { Light green: } \epsilon & =1.556-1.562(1.559) \\
\omega & =1.558-1.566(1.562) \\
\text { Dark green: } \epsilon & =1.555-1.565(1.560) \\
\omega & =1.560-1.568(1.564)\end{aligned}$ \\
\hline Birefringence ${ }^{b}$ & $\begin{array}{ll}\text { Light green } & =0.003 \\
\text { Dark green } & =0.004\end{array}$ \\
\hline $\begin{array}{l}\text { Specific } \\
\text { gravityc }\end{array}$ & Around $2.65-2.66$ \\
\hline Inclusions & $\begin{array}{l}\text { Opaque, tube-like inclusions aligned } \\
\text { parallel to the c-axis; sequential growth } \\
\text { layers, with primary flux inclusions and } \\
\text { foreign crystallites; slender prismatic } \\
\text { crystals of synthetic phenakite and } \\
\text { synthetic beryl; "wispy veils," two-phase } \\
\text { inclusions. }\end{array}$ \\
\hline
\end{tabular}

aAs observed through a hand-held type of spectroscope.

bThe extreme values of the constants are given, with mean

values in parentheses. Birefringences are given for the mean

values.

cEstimated with heavy liquids.

Color-Filter Reaction. Observed through the Chelsea filter, the crystals appear a vivid red, again as can be seen in many natural emeralds.

Specific Gravity. The specific-gravity values for flux-grown synthetic emeralds of various manufacturers are frequently lower than the values for natural emeralds; flux-grown synthetic emeralds usually float when tested in a standard 2.67 (specific gravity) heavy liquid. A few of the Lennix synthetic emeralds were tested in 2.67 liquid; on the basis of the rate of ascent, the specific gravity was estimated to be approximately $2.65-2.66$.

Absorption Spectra. The visible-light absorption spectrum of the faceted Lennix synthetic emerald shown in figure 1 was examined with a Beck handheld type of spectroscope. The observed spectrum appeared to be the same as that previously described for both synthetic and natural emerald (Liddicoat, 1981). This optical absorption spectrum was confirmed, using a Cary 219 dual-beam spectrophotometer, over the spectral range from 400 to $800 \mathrm{~nm}$. The following were identified: a doublet at 683 and $680 \mathrm{~nm}$; bands at 662,646, and $637 \mathrm{~nm}$; and a wide band between 610 and $590 \mathrm{~nm}$. An additional line at $477 \mathrm{~nm}$ can be seen only when looking at the spectrum down the optic axis direction (i.e., parallel to the c-axis); it is not visible when the spectrum is examined perpendicular to the optic axis. This phenomenon was observed with both the "hand-held" spectroscope and the spectrophotometer.

Fluorescence. When exposed to long-wave ultraviolet radiation, the specimens glowed bright red, and with short-wave U.V. radiation they revealed both transparency and a dim orange-red fluorescence. While this fluorescence might be an indicator that the stone is synthetic, it should be noted that some high-chromium Colombian emeralds will fluoresce bright red to long-wave U.V. radiation. Exposure to X-rays caused a distinct, yet dull, red fluorescence.

\section{CHEMISTRY AND ADDITIONAL TESTING}

Chemical Analyses. Each specimen was analyzed by means of a JEOL JXA-50A electron microprobe on both the pale green and the deep green zones. The chemical data reported in table 2 refer to average values obtained from no less than five spots for each sample.

The data show fairly high contents of $\mathrm{FeO}$ and $\mathrm{MgO}$ for a synthetic emerald and low ampunts of alkalies as compared to most natural emeralds. However, the $\mathrm{FeO}$ and $\mathrm{MgO}$ contents are lower than the average in most natural emeralds and, along with the low content of alkalies, may be responsible for the low refractive-index, birefringence, and specific-gravity values (Folinsbee, 1941; Sherstyuk, 1958; Winchell and Winchell, 1951). The chromium content in the deep green areas is high, but is comparable with data reported for natural and other synthetic emeralds.

Cathodoluminescence. Cathodoluminescence determinations were carried out on all samples using a luminoscope manufactured by Nuclide Corp. 
USA. Electrons were produced using pure helium as a carrier gas. The data obtained were quite similar for all samples. Red luminescence similar to or weaker than that of Chatham or Linde hydrothermal synthetic emeralds - but more intense than that of natural Colombian emeraldswas observed in all cases. In some of the synthetic Lennix emeralds tested, the luminescence excited by cathode rays was different at the edges and within a narrow outer zone (red) from that seen in the interior (violet-blue or purple). No other emeralds (synthetic or natural) tested thus far have displayed the purple or bright violet-blue luminescence observed in the Lennix specimens.

X-Ray Diffraction Data. Microsamples labout 20-30 $\mu \mathrm{m}$ in diameter) were isolated by means of the MEA apparatus (Graziani, 1983), within both the deep green and the pale green zones of all the specimens. Subsequently, X-ray diffraction patterns were obtained using a Gandolfi camera (Gandolfi, 1967), and unit-cell parameters were estimated by a least-squares refinement of the diffraction data (Farinato and Loreto, 1975; De Angelis èt al., 1977), indexed by comparison with those listed by JCPDS. The results for the light green areas were $\underline{\mathrm{a}}=9.203 \pm 0.002 \AA, \underline{\mathrm{c}}=9.181 \pm$ $0.004 \AA$; for the dark green areas, they were $\mathrm{a}=$ $9.202 \pm 0.003 \AA, \underline{c}=9.187 \pm 0.005 \AA$.

X-ray Topography. Experiments were carried out on slabs of the synthetic Lennix emeralds cut perpendicular to the c-axis and polished by standard procedures (Scandale et al., 1979).

The tests were performed by means of a Lang camera, recorded on llford high-resolution plates, using $\mathrm{Mo}_{\mathrm{K} \alpha 1}$ radiation. The topography was remarkable in the contrasting features that covered the entire surface and permit reconstruction of the grow th history of the examined crystal. In fact, the sample resulted from the aggregation of different smaller crystals around a subhexagonal central nucleus. This kind of growth is quite different from that of natural emeralds, in which the crystals grew during a slow cooling of the parent solution, and is thus typical of synthetic beryl grown in flux conditions.

Infrared Spectra. Infrared spectra in the range 4000 to $600 \mathrm{~cm}^{-1}$ were obtained on a Perkin Elmer 398 filter grating spectrometer, using I $\mathrm{mg}$ of beryl in 200-mg KBr discs. The bands at 3590 and 3694 $\mathrm{cm}^{-1}$ that are normally observed in natural emer-
TABLE 2. Results of the chemical analyses of the pale green and deep green areas of eight rough and one faceted Lennix synthetic emerald a

\begin{tabular}{lcc}
\hline Oxide & $\begin{array}{c}\text { Pale green areas } \\
(w t . \%)\end{array}$ & $\begin{array}{c}\text { Deep green areas } \\
\text { (wt.\%) }\end{array}$ \\
\hline $\mathrm{SiO}_{2}$ & 65.83 & 66.04 \\
$\mathrm{Al}_{2} \mathrm{O}_{3}$ & 18.02 & 18.03 \\
$\mathrm{Cr}_{2} \mathrm{O}_{3}$ & 0.57 & 1.19 \\
$\mathrm{FeO}^{b}$ & 0.50 & 0.70 \\
$\mathrm{BeO}$ & 13.06 & 12.31 \\
$\mathrm{MgO}$ & 0.46 & 0.44 \\
$\mathrm{MnO}$ & 0.07 & 0.06 \\
$\mathrm{Na}_{2} \mathrm{O}$ & 0.32 & 0.21 \\
$\mathrm{~K}_{2} \mathrm{O}$ & 0.14 & 0.14 \\
$\mathrm{H}_{2} \mathrm{O}$ & 0.06 & 0.08 \\
$\mathrm{CO}_{2}$ & & \\
$\mathrm{Totalc}$ & 99.03 & 99.20 \\
\hline
\end{tabular}

aAll oxides were determined by electron microprobe excepl: Be was determined by the pyrophosphate method, and $\mathrm{H}_{2} \mathrm{O}$ plus $\mathrm{CO}_{2}$ were determined thermogravimetrically. The results reported are average values.

bTotal iron as $\mathrm{FeO}$

-The following elements were checked but not detecled: $\mathrm{Ti}, \mathrm{V}, \mathrm{Ca}$ $B a, C s$. Not recognized with spectrographic method: $L i$.

alds seem to be totally absent, as would be expected for a flux-grown synthetic emerald (Flanigen et al., 1967), thus yielding another valuable means of distinction. However, infrared spectra in the same range that were obtained from polished slabs oriented parallel to the c-axis showed less distinct features.

Microscopic Examination of Inclusions. The Lennix synthetic emerald samples were examined with a gemological binocular microscope in transmitted light and under crossed polars. The specimens are characterized by a variety of inclusions that may generally be divided into five categories:

I. Opaque, tube-like inclusions aligned preferentially parallel to the c-axis (figures 2-4)

2. Clusters of inclusions along the borders of sequential growth zones that parallel the edges of the basal pinacoid (figure 5)

3. Slender, subhedral prismatic crystals of synthetic phenakite and beryl (figures 6-8)

4. Secondary flux-lined healed fractures that at low magnification look like "wispy veils" (figure 9)

5. Two-phase inclusions grouped along the edges of the basal pinacoid and sometimes parallel to the c-axis (figures 4 and 10 ) 


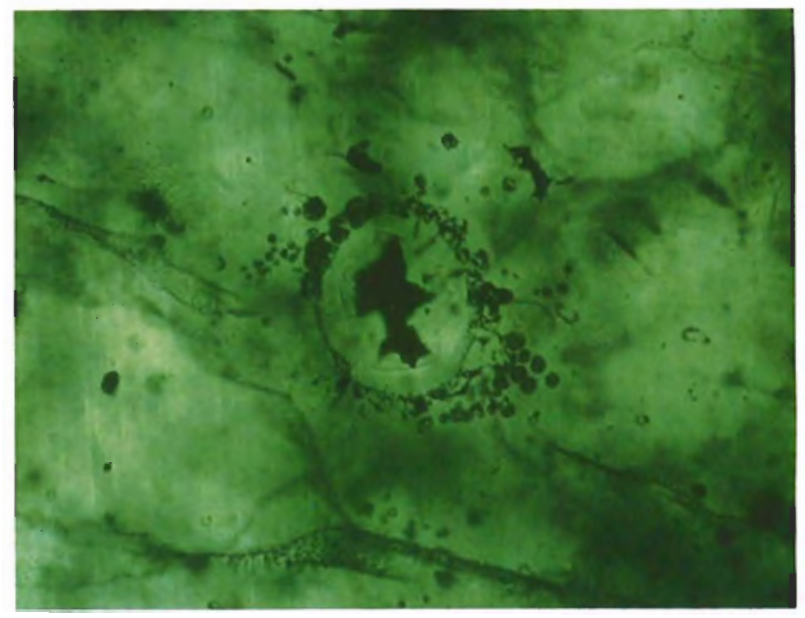

Figure 2. This partly flux-filled $\left(\mathrm{MoO}_{3}\right)$ tubelike inclusion in a Lennix synthetic emerald is surrounded by peripheral synthetic beryl crystals. A number of wispy veil-like inclusions characteristic of flux-grown synthetic emeralds are also evident. Transmitted light, magnified $30 \times$

Figure 4. These irregular, opaque $\mathrm{MoO}_{3}$ flux inclusions are accompanied by peripheral synthetic beryl crystallites and two-phase inclusions. Transmitted light, magnified $64 \times$.

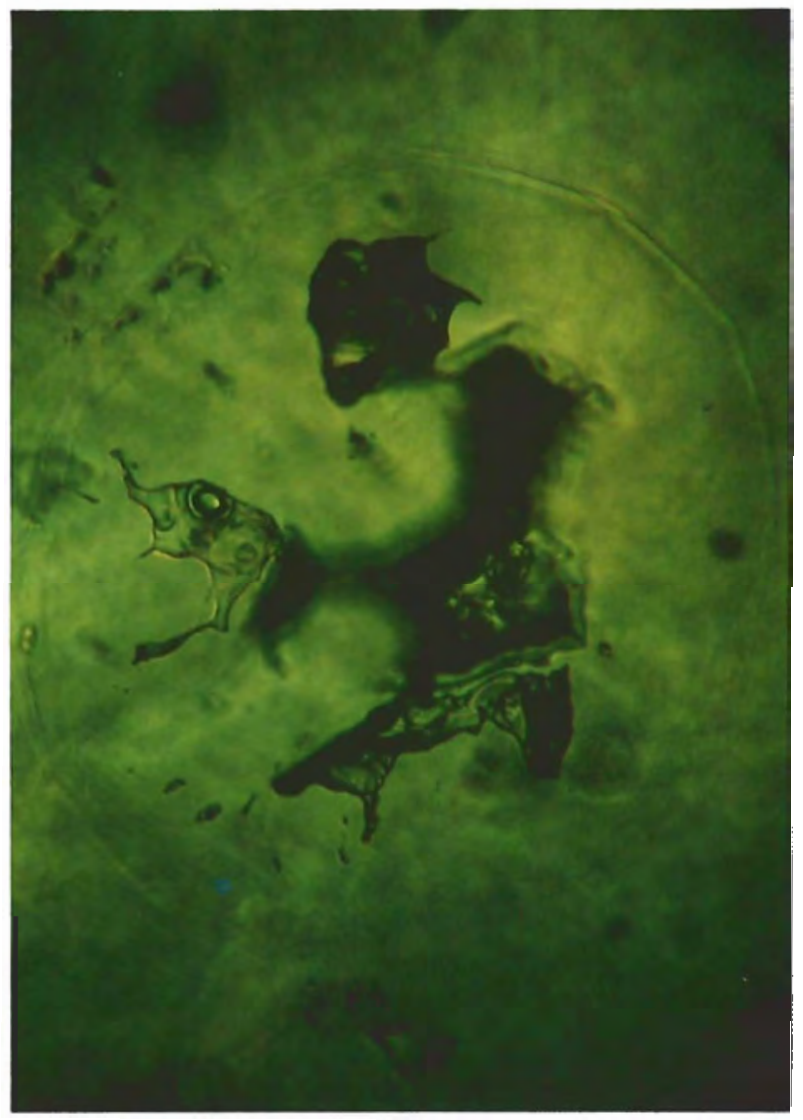

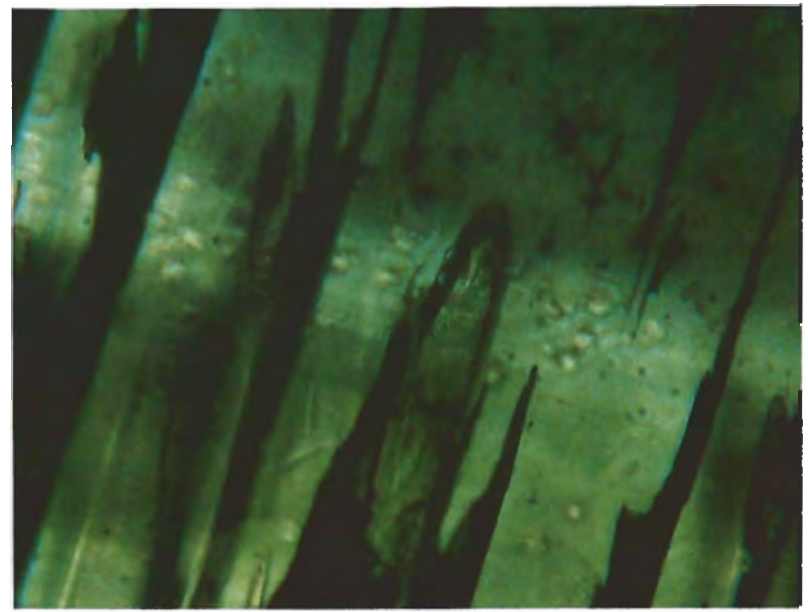

Figure 3. A different view of a number of tubelike inclusions similar to the one seen in figure 2 shows that they are oriented in channels that run parallel to the c-axis. Transmitted light, magnified $100 \times$.

Figure 5. Color zones, representing the various stages of growth of the synthetic emerald, echo the hexagonal frame of the Lennix crystal growth. On this basal plane, a number of dichroic synthetic beryl crystals are evident. Transmitted light, magnified $10 \times$.

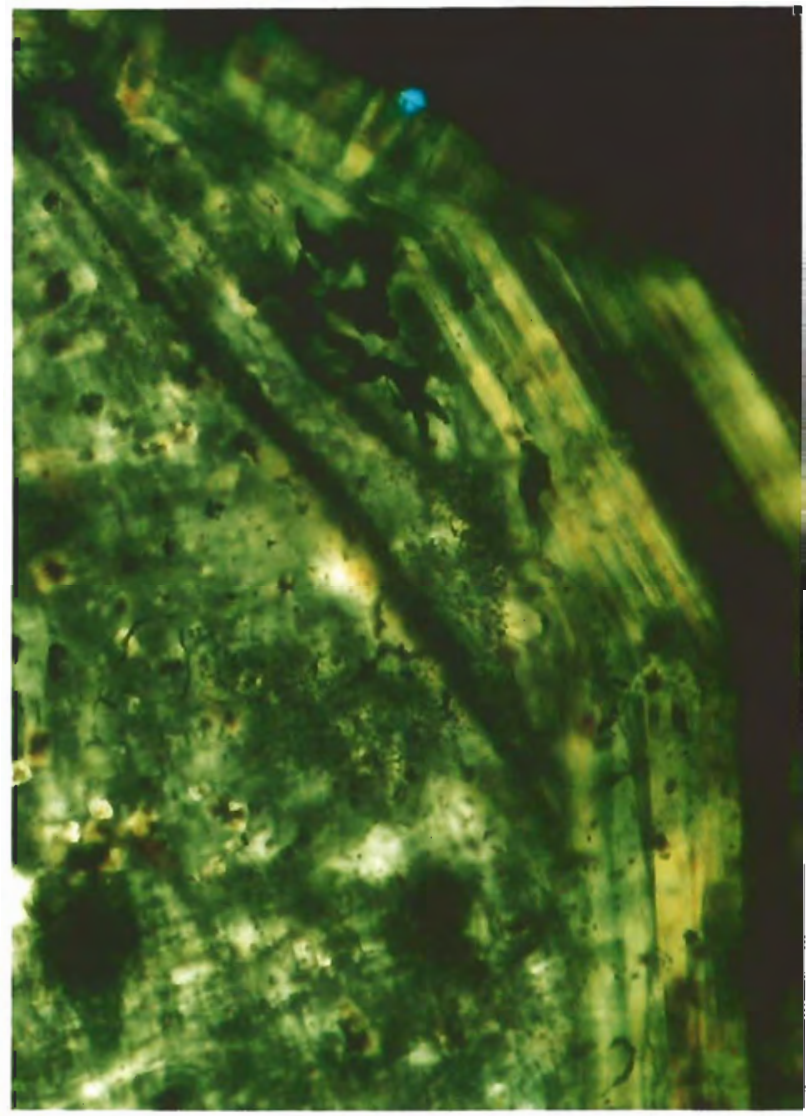




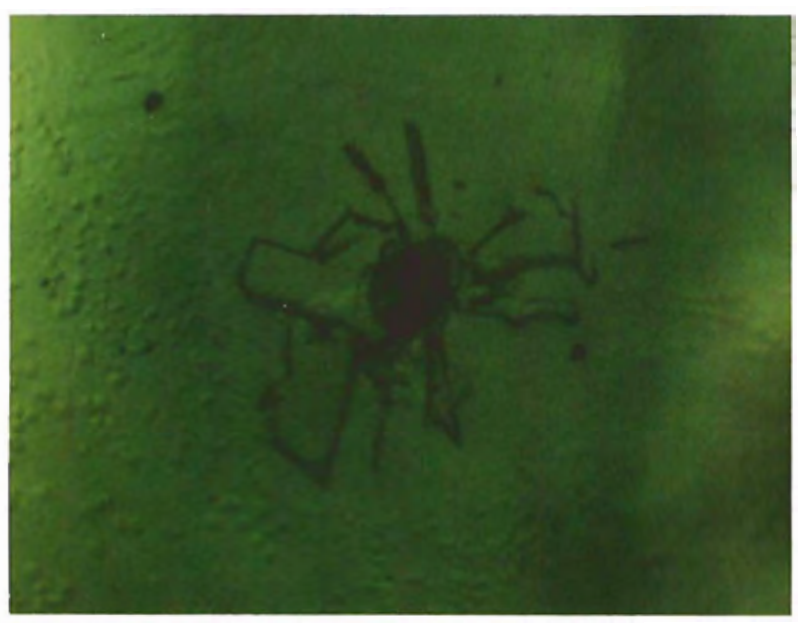

Figure 6. This spider-like configuration in a Lennix synthetic emerald proved to be a grouping of crystals of synthetic phenakite. Transmitted light, magnified $100 \times$

Opaque, Tube-like Inclusions. X-ray transmission micrographs were made on the opaque, tube-like inclusions oriented in channels (figures 2-4). These analyses identified subordinate crystals of synthetic beryl along the channel walls, and a thin film of flux which was opaque to X-ray microradiography. Chemical analysis of the flux proved it to be molybdenum oxide $\left(\mathrm{MoO}_{3}\right)$.

Growth Zoning and Associated Inclusions. Optical observations attest to the presence of various stages of crystal growth. Along the edges of these growth zones, two kinds of associated inclusions are evident: minute euhedral synthetic beryl crystals (figure 5) and clusters of synthetic phenakite. X-ray diffraction patterns identified the latter inclusions (JCPDS card no. 9-431). This identification was confirmed by microprobe analysis and subsequent stoichiometric elaboration of the chemical data.

Other Crystal Inclusions. The Lennix synthetic emerald also contains discrete, minute, acicular, prismatic crystals that sometimes consist of tri- and poly-angular associations (figure 6). The chemical composition of these inclusions is typical of phenakite and very similar to that of the clusters described previously.

Transparent subhedral prismatic crystals lapproximately $0.05 \times 0.03 \mathrm{~mm}$ ) were also observed perpendicular to the $\mathrm{c}$-axis of the synthetic host emerald. Not only are the refractive indices of these crystal inclusions similar to those of the synthetic host emerald, but microchemical analyses also revealed that they are similar in chemi-

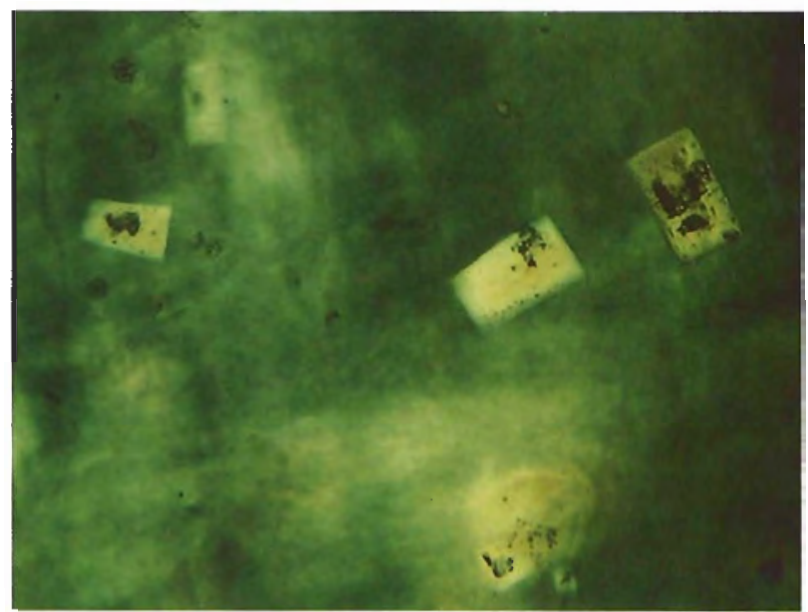

Figure 7. Individual crystals of synthetic beryl are observed at right angles to their c-axes in this Lennix synthetic emerald. Crossed polars, magnified $30 \times$.

cal composition to the host, particularly to the deep green zones (table 2). Consequently, these inclusions were determined to be synthetic beryl (figures 7 and 8).

Figure 8. An opaque black flux inclusion marks the center of this greatly enlarged synthetic beryl crystal in a Lennix synthetic emerald. Crossed polars, magnified $150 \times$.

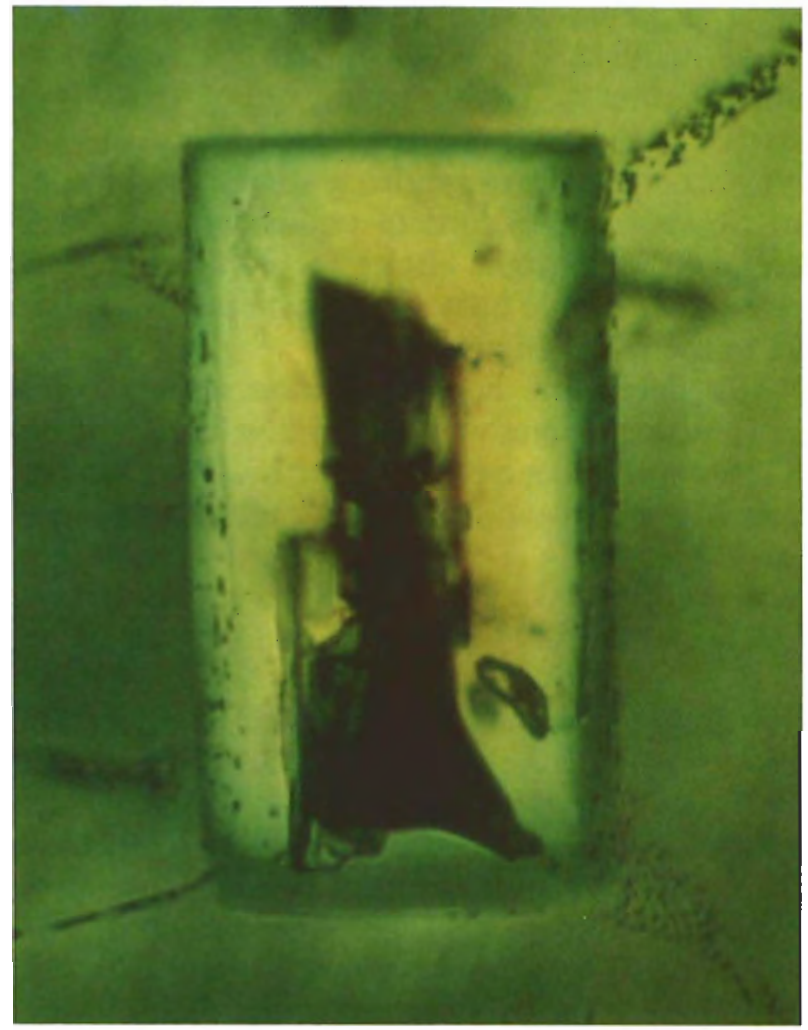




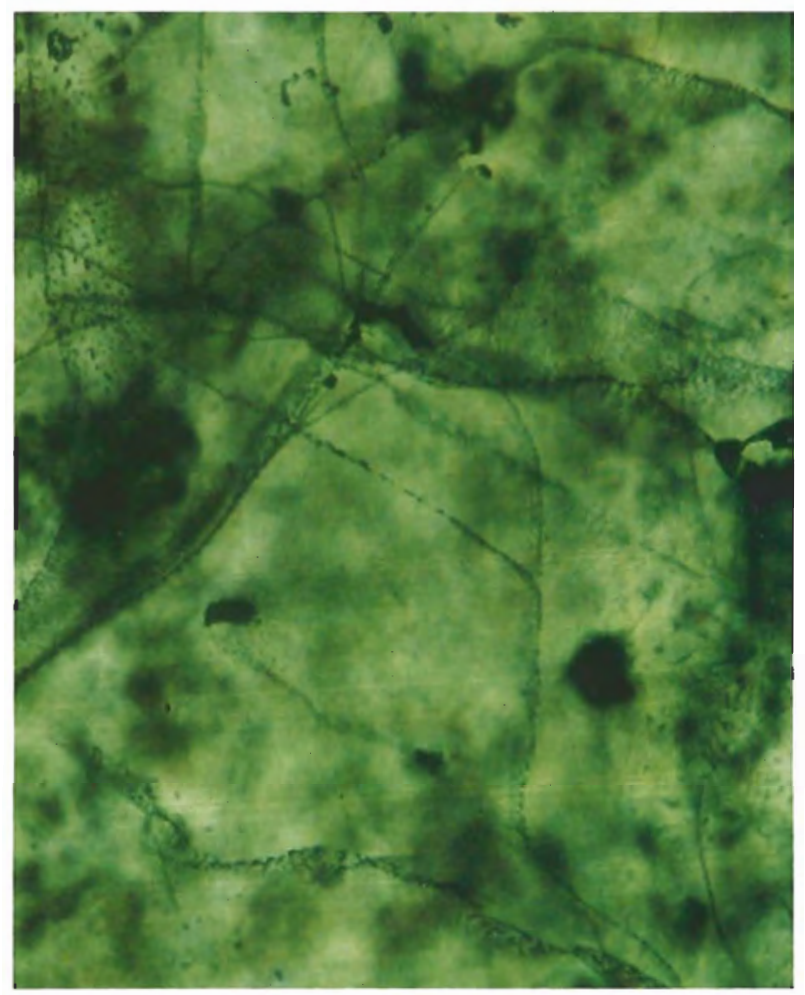

Figure 9. These delicate "wispy veils" are actually secondary flux-lined healed fractures in the Lennix synthetic emerald. Transmitted light, magnified $15 \times$.

The whole crystal also contains many twophase inclusions in wisp- or veil-like configurations [figure 9|. These "wispy veils"-more precisely, secondary flux-lined healed fractures-are typical of flux-grown synthetic stones. In addition, small, sporadic swarms of two-phase inclusions occur either at right angles to the c-axis of the synthetic emerald host or, more frequently, parallel to the c-axis (figure 10).

To determine homogenization temperatures for these inclusions, we used a Nikon Optiphot Pol. XTP-11 microscope equipped with a Fluid Inc. gas flow heating/freezing system for temperatures up to $700^{\circ} \mathrm{C}$ and a Leitz 1350 device for higher temperatures. At least nine hours of isothermal heating were used for each run. Homogenization could not be observed up to $800^{\circ} \mathrm{C}$.

Two-phase inclusions with internal crystallization products were sectioned by MEA for analysis. Optical investigations showed that the internal walls of these inclusions are covered by irregularly shaped crystals with a chemical composition very close to that of the synthetic host emerald.

These considerations suggest that, after the formation of the cavities and before their closure

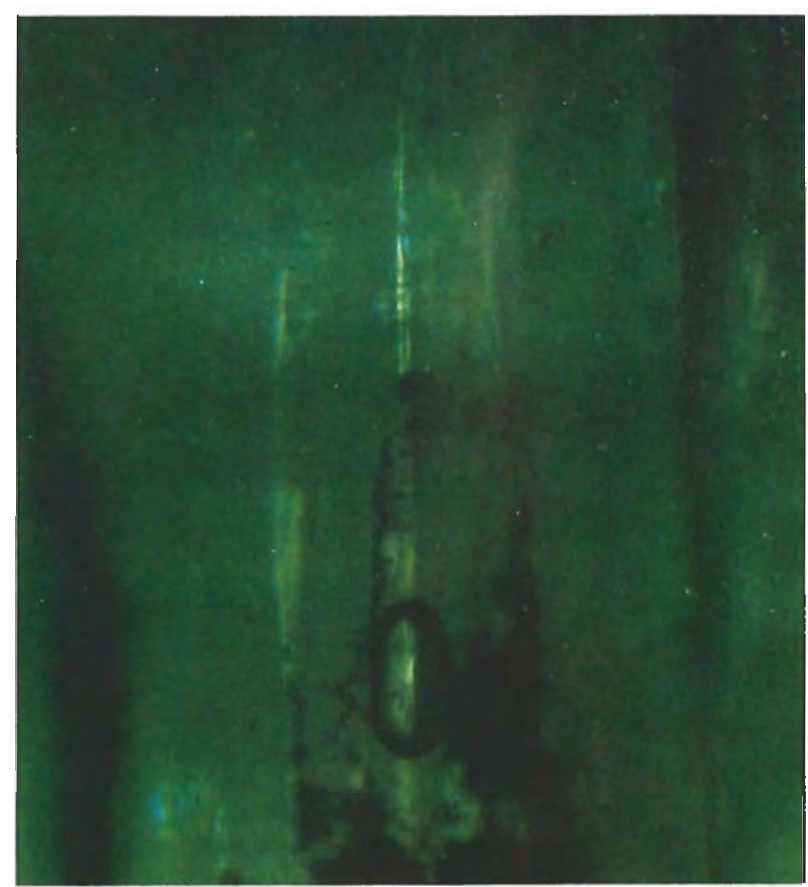

Figure 10. In this greatly enlarged two-phase inclusion, the large oval bubble that corroborates the second phase is probably in a glassy flux relic. The inclusion runs parallel to the $c$-axis of the host. Transmitted light, magnified $100 \times$.

(sealing), beryl crystallization occurred. This phenomenon is very close to that described by Yermakov (1965) as a deposition of the cognate substance on the inclusion wall.

\section{CONCLUSION}

For the gemologist, the very fact that the Lennix synthetic emeralds are so heavily included can cause problems, because they superficially resemble poor-quality natural emeralds. If, however, wispy veil-like partially healed fractures (similar to those shown in figure 9) are present, then regardless of the other inclusions (which may somewhat resemble those seen in natural emeralds), the stone can be identified as synthetic. The low refractive-index and specific-gravity values are also indicative of flux-grown synthetic emeralds; when these are obtained in conjunction with the observation of "wispy veils," they conclusively prove synthesis.

Where available, more sophisticated chemical analyses, infrared spectra, and cathodoluminescence experiments all provide effective means of differentiating the Lennix synthetic emerald from both natural emeralds and other synthetic emeralds. 


\section{REFERENCES}

De Angelis G., Farinato R., Loreto L. (1977) The crystal lattice constants refinement: a least-squares procedure for the direct or reciprocal case. Rendiconti della Società Italiana di Mineralogia e Petrologia, Vol. 33, pp. 3-14.

Farinato R., Loreto L. (1975) A least-squares refinement of crystals lattice constants and evolution of their errors, using the direct unit-cell. Rendiconti della Societa Italiana di Mineralogia e Petrologia, Vol. 31, pp. 486-500.

Farn A.E. (1980) The Lennix emerald. Journal of Gemmology, Vol. 17, No. 2, pp. 73-80.

Flanigen E.M., Breck I.W., Mumbach N.R., Taylor A.M. (1967) Characteristics of synthetic emeralds. American Mineralogist, Vol. 52, pp. 744-772.

Folinsbee R.E. (1941) Optic properties of cordicrite in relation to alkalies in the cordierite-beryl structure. American Mineralogist, Vol. 26, pp. 485-500.

Gandolfi G. (1967) Discussion upon methods to obtain X-ray "powder patterns" from a single crystal. Mineralogica et
Petrografica Acta, Vol. 13, pp. 67-74.

Graziani G. (1983) Advances in the study of mineral inclusions. Neues Jarbuch für Mineralogie Monatshefte, Vol. 11, pp. $481-488$.

Liddicoat R.T. Jr. (1981) Handbook of Gem Identification, 11th ed. Gemological Institute of America, Santa Monica, CA. Scandale E., Scordari F., Zarka A. (1979) Étude dés défauts dans des monocristaux naturels de beryl, l: Observations des dislocations. Journal of Applied Crystallography, Vol. 12, pp. $70-77$.

Sherstyuk A.l. (1958) The influence of isomorphous impurities in beryl on its refractive indices. Doklady Akademii Nauk SSSR, Vol. 2, pp. 5l-56.

Winchell A.N., Winchell H. (1951) Elements of Optical Mineralogy, Vol. 2, 4th ed. John Wiley, New York.

Yermalkov N.P. (1965) Research on the Nature of Mineralforming Solutions, 1st ed. Pergamon Press, New York.

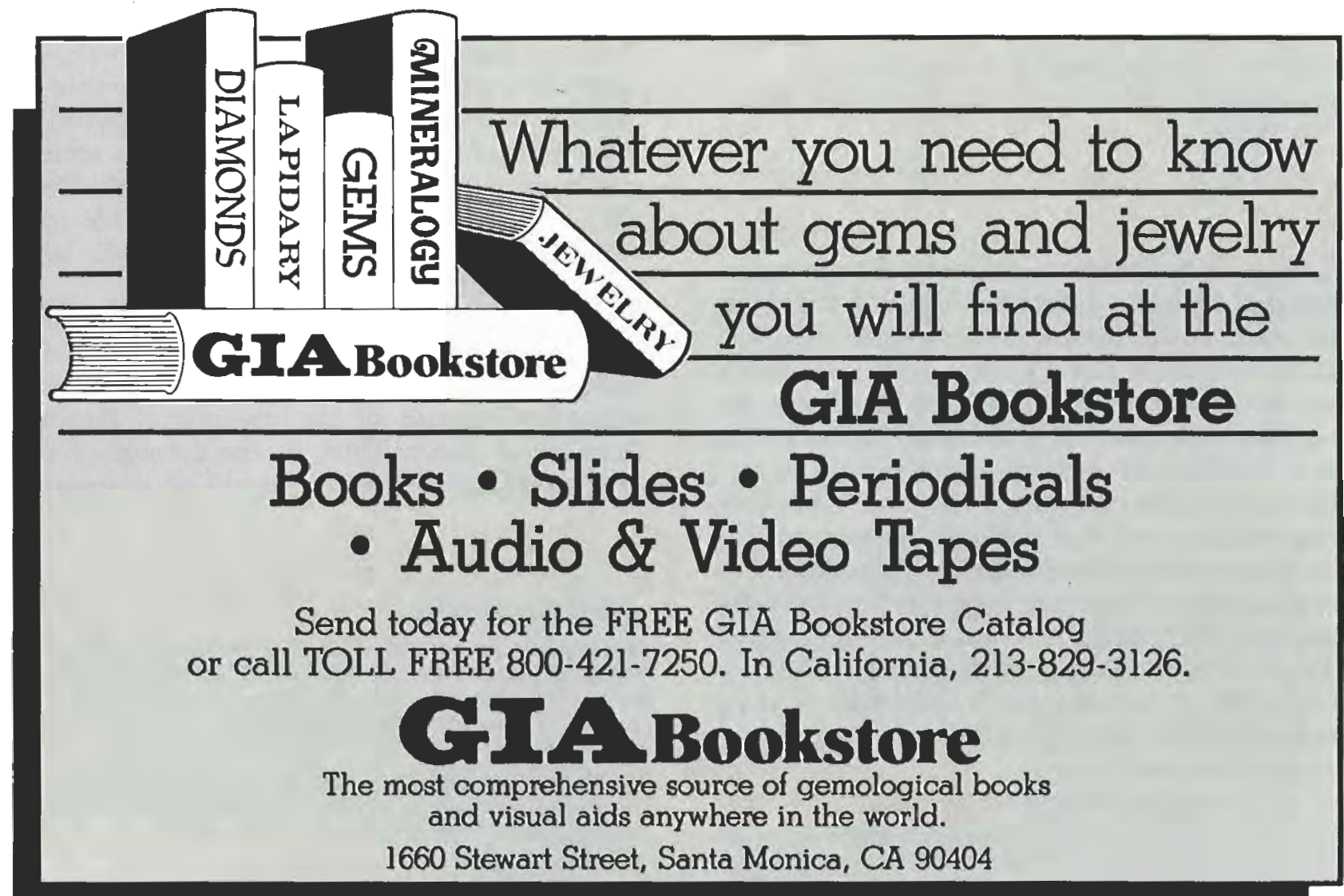

